\title{
Analisis Perbandingan Penghimpunan Dana Pihak Ketiga Bank Syariah Sebelum dan Sesudah Kebijakan Tax Amnesty
}

\author{
Tk. Umar Johan \& Muslikhati \\ Program Studi Ekonomi Syariah, Fakultas Agama Islam, \\ Universitas Muhammadiyah Malang \\ E-mail: tkumarjohan@live.com
}

\begin{abstract}
This study aims to reveal the comparison of Third Party Funds (DPK) of sharia bank as Bank Perception Tax Amnesty policy in 2016.This study used a comparative quantitative approach with the subject of research is the Third Party Funds of sharia bank the receiver of Tax Amnesty funds in 2016. The selection of DPK as a research setting based on the existence of funds for bank is vital for business continuity, because without sufficient funds the bank will not be function properly. The determination of samples was decided by Ministry of Economic in Republic Indonesia No.600/KMK.03/2016, so the sample of this research compare within 3 banks, those are; Bank Muamalat Indonesia, Bank Negara Indonesia Syariah, and Bank Syariah Mandiri. The test equipment used Paired Sample T-Test assisted software SPSS 21. The result of Paired Sample T-Test founded that there was $\alpha P$ value t equal to 0,000 or $<0,05$, means a significant difference of DPK accumulation before and after Tax Amnesty policy in 2016. The average of DPK sharia bank before Tax Amnesty policy accumulated Rp 124,1 Trillion and increased Rp 132,9 Trillion after Tax Amnesty policy.
\end{abstract}

Keywords: Sharia Bank, Third Party Funds, Tax Amnesty

\section{Pendahuluan}

Pembangunan ekonomi merupakan kewajiban suatu negara untuk dapat meningkatkan taraf hidup dan kesejahteraan rakyat termasuk Indonesia. Upaya negara dalam rangka melaksanakan tugas dan kewajibannya, tentu harus ada pembiayaan yang memadai. Masalah pembiayaan negara meliputi, pertama pendapatan negara yaitu sumber-sumber pendapatan tertentu dan dari sumber pendapatan warga negara, antara lain berupa pajak, kedua pembelanjaan atau 
pengeluaran negara yaitu biaya yang dikeluarkan negara untuk menjalankan roda organisasinya.

Pajak dalam pandangan Islam merupakan suatu bentuk muamalah dalam bidang ekonomi. Pajak memang bukan kewajiban agama selayaknya zakat yang memang diwajibkan dan akan berdosa bila enggan membayarnya. Pajak merupakan salah satu bentuk ijtihad baru guna mewujudkan kemaslahatan baik bagi masyarakat maupun negara. ${ }^{1}$ Adanya pajak, masyarakat pun akan merasakan hasilnya. Masyarakat bisa menikmati dan memanfaatkan sarana dan prasarana umum yang tersedia seperti sarana transportasi, pendidikan, kesehatan, komunikasi, keamanan, hukum dan sarana kegiatan lainnya yang mendukung kegiatan sehari-hari. Pajak merupakan sumber penerimaan negara yang berperan besar bagi kelangsungan negara. Penerimaan pajak di Indonesia merupakan sumber dana utama yang sangat berpotensi dan mendominasi pendapatan negara, yaitu $86.17 \%$ dari penerimaan Anggaran Pendapatan dan Belanja Negara $(\mathrm{APBN}){ }^{2}$ Besarnya ketergantungan pemerintah terhadap penerima sektor perpajakan, ternyata tidak selaras dengan realisasi pencapaian target penerimaan pajak selama ini. Realisasi penerimaan pajak selama 10 tahun terakhir selalu di bawah target (kecuali di tahun 2008), dengan pencapaian tax ratio berada di angka $11-13 \%$. Buruknya situasi perpajakan tidak terlepas dari kepatuhan Wajib Pajak (WP) yang masih rendah. ${ }^{3}$ Kondisi ini mengindikasikan perlunya suatu upaya pembenahan atau reformasi secara komprehensif di sektor perpajakan.

Pembenahan sebagai upaya untuk meningkatkan penerimaan negara dari sektor perpajakan serta guna meningkatkan tax ratio pada tahun 2016 dan tahuntahun berikutnya, melalui intensifikasi dan ekstensifikasi perpajakan salah satunya dengan kebijakan Pengampunan Pajak atau Tax Amnesty. Program ini merupakan kebijakan pemerintah yang diberikan kepada WP tentang Pengampunan Pajak, dan sebagai ganti atas pengampunan tersebut WP diharuskan membayar uang tebusan. Kebijakan Tax Amnesty tersebut tidak terlepas dari peranan perbankan. Berdasarkan Keputusan Menteri Keuangan Republik Indonesia No. 600/KMK. 03/2016 tentang penetapan Bank Persepsi (BP) yang bertindak sebagai penerima uang tebusan dalam rangka pelaksanaan Pengampunan Pajak menetapkan 77 Bank terdiri dari 49 Bank Umum Konvensional (BUK), 25 Bank Pembangunan Daerah (BPD) dan 3 Bank Umum Syariah (BUS) sebagai penampung dana Tax Amnesty. ${ }^{4}$ Terpilihnya 3 Bank Umum Syariah (Bank Muamalat Indonesia, Bank Negara Indonesia Syariah dan Bank Syariah Mandiri) melalui proses seleksi dan

\footnotetext{
1 Mudawamah, "Penyanderaan (Gijzeling) Terhadap Wajib Pajak Pribadi yang Tidak Kooperatif' (Skripsi Sarjana Hukum Bisnis Syariah Fakultas Syariah UIN Malik Ibrahim, Malang 2015), 2.

2 Direktorat Jenderal Anggaran, Nota Keuangan APBN-P 2016, I.1-5.

${ }^{3}$ Danny Darussalam Tax Center, "Kinerja Penerimaan Pajak Jangka Panjang," InsideTax, Ed. 36 (Januari, 2016), 34-35.

${ }^{4}$ Menteri Keuangan RI, KMK RI No. 600/KMK.03/2016 Tentang Penetapan Bank Persepsi yang Bertindak Sebagai Penerima Uang Tebusan dalam Rangka Pelaksanaan Pengampunan Pajak, 3-4.
} 
telah memenuhi syarat yang ditetapkan pemerintah. Tergolong sebagai lembaga keuangan syariah yang ditetapkan pemerintah sebagai Bank Persepsi, kesempatan ini harus dimanfaatkan dengan baik, mengingat pemerintah menargetkan perolehan uang tebusan sebesar Rp 165 Triliun, dengan dana repatriasi mencapai Rp 1.000 Triliun, dan dana deklarasi sebesar Rp 4.000 Triliun baik dari dalam maupun luar negeri. ${ }^{5}$ Maka, jika target penerimaan dana tersebut masuk dan terinvestasikan di Bank Persepsi, jelas hal ini akan berdampak terhadap kinerja keuangan. Kebijakan Tax Amnesty dapat memberikan kontribusi positif untuk kinerja keuangan perbankan seperti Dana Pihak Ketiga (DPK).

Dana Pihak Ketiga adalah dana yang dihimpun dari masyarakat, dalam arti masyarakat sebagai individu, perusahaan, pemerintah, rumah tangga, koperasi, yayasan, dan lain-lain baik dalam mata uang rupiah maupun dalam valuta asing. ${ }^{6}$ Pertumbuhan setiap bank sangat dipengaruhi oleh perkembangan penghimpunan dana masyarakat baik berskala kecil maupun besar dengan masa investasi yang memadai. ${ }^{7} \mathrm{Hal}$ ini dikarenakan masalah bank yang utama adalah dana, tanpa dana yang cukup bank tidak akan berfungsi sebagaimana mestinya. Penghimpunan dana pada bank dapat berbentuk Giro, Tabungan, dan Deposito yang secara total biasa disebut Dana Pihak Ketiga. Dana Pihak Ketiga merupakan dana terbesar yang dimiliki oleh suatu bank. Besarnya proporsi dana menunjukkan bahwa keberadaan DPK menjadi unsur vital bagi kinerja keuangan perbankan. DPK unsur pembentuk pendapatan karena DPK pada perbankan syariah akan disalurkan dalam bentuk pembiayaan. Pembiayaan yang disalurkan tersebut akan diperoleh tingkat pengembalian berupa margin, besar kecilnya margin akan menentukan tingkat profitabilitas. Maka optimalisasi penghimpunan DPK menjadi sangat penting dalam meningkatkan profitabilitas. ${ }^{8}$

Besar kecilnya Dana Pihak Ketiga yang berhasil dihimpun sangat bergantung pada manajemen perbankan itu sendiri. Bagusnya pelayanan dan menarik produk simpanan yang ditawarkan maka akan dapat mempengaruhi masyarakat untuk menabung, deposit, atau jadi nasabah giro, sehingga ketersediaan dana cukup untuk aktivitas pembiayaan. DPK bagian terpenting dalam basis keputusan atau kebijakan dalam bank, apabila DPK dalam keadaan stabil maka hal ini akan memberikan tingkat kepastian keputusan dalam pemberian kredit/pembiayaan. Karena semakin besar DPK maka keputusan pemberian pembiayaan akan semakin tinggi pula. DPK berpengaruh positif terhadap penyaluran pembiayaan. Ketika dana-dana yang terkumpul dari

5 Yang Perlu Anda tahu Tentang Amnesti Pajak, diakses pada tanggal 28 Juli 2017 dari http://pajakku.com/page/detail/999/yang-perlu-anda-tahu-tentang-amnesti-pajak.

${ }^{6}$ Veitzhal Rivai, et al., Bank and Finansial Institution Management: Conventional \& Sharia System (Jakarta: Rajawali Pers, 2007), 413.

${ }^{7}$ Teti Rahmawati, “Analisis Perbandingan Penghimpunan Dana Pihak Ketiga Pada Perbankan Syariah Sebelum dan Sesudah Penerapan Kebijakan Office Chanelling”, Jurnal Riset Keuangan dan Akuntansi, Vol. 1 No. 2 (2015), 76.

${ }^{8}$ Maltuf Fitri, "Peran Dana Pihak Ketiga dalam Kinerja Lembaga Pembiayaan Syariah dan Faktor-faktor yang Mempengaruhinya", Jurnal Economica, Vol. VII, Ed. 1 (Mei 2016), 74. 
masyarakat tinggi, maka keputusan untuk menyalurkan pembiayaan akan semakin tinggi pula. ${ }^{9}$

Berdasarkan data publikasi Statistik Perbankan Syariah (SPS) Otoritas Jasa Keuangan (OJK) pertumbuhan DPK Bank Umum Syariah dan Unit Usaha Syariah (UUS) 5 tahun terakhir terus meningkat, pada tahun 2012 total DPK adalah sebesar Rp 147,5 Triliun, Rp 183,5 Triliun (2013), Rp 217,8 Triliun (2014), Rp 231,2 Triliun (2015), dan pada tahun 2016 sebesar Rp 279,3 Triliun. $^{10}$ Data tersebut menunjukkan DPK dari seluruh perbankan syariah di Indonesia, pada tahun 2016 mengalami pertumbuhan 20,8\%. Persentase peningkatan ini pun mengalami lonjakan yang signifikan dibanding periode sebelumnya yang hanya 6\%.Lebih spesifik, perkembangan penghimpunan Dana Pihak Ketiga Bank Umum Syariah dan Unit Usaha Syariah di Indonesia yang terdiri dari Giro, Tabungan, dan Deposito sebagaimana dalam Gambar 1.1 berikut.

Gambar 1.1 Grafik Perkembangan Penghimpunan Dana Pihak Ketiga Bank Umum Syariah dan Unit Usaha Syariah di Indonesia

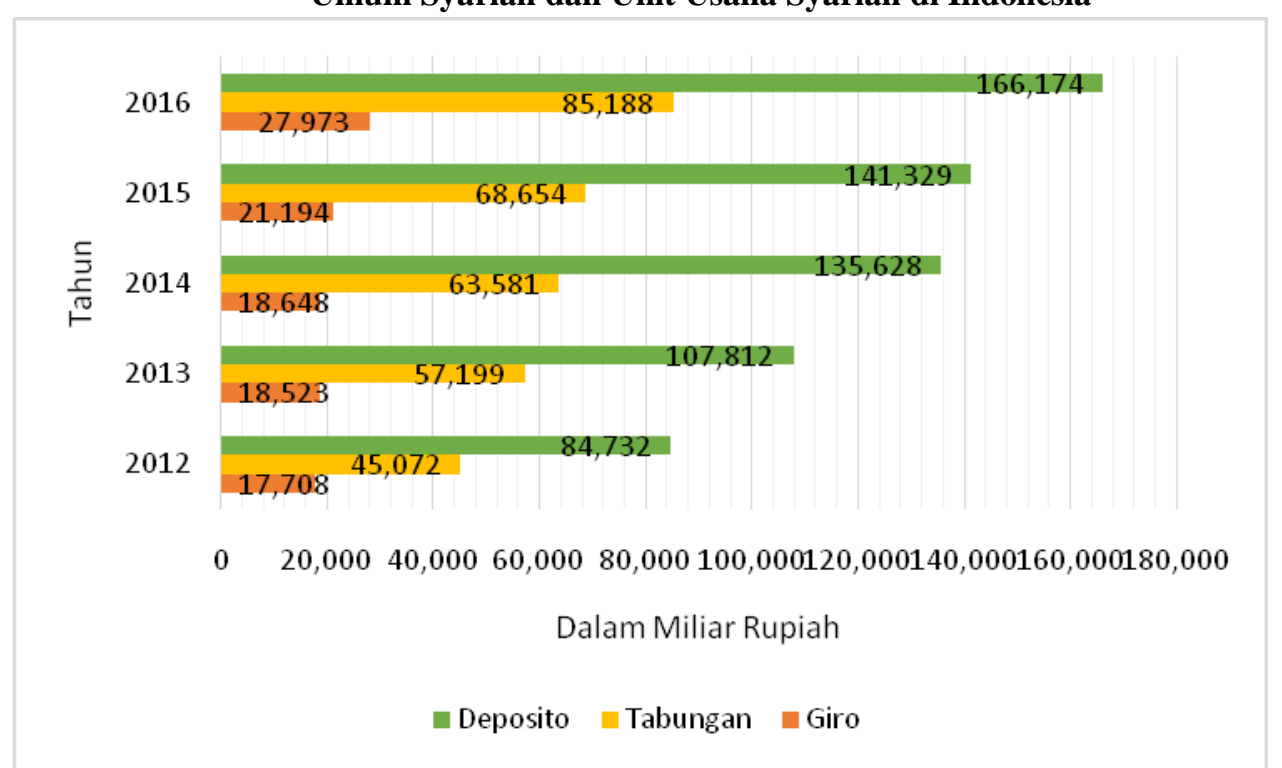

Sumber: Statistik Perbankan Syariah Otoritas Jasa Keuangan

Komposisi Dana Pihak BUS dan UUS pada Gambar 1.1 didominasi Deposito, kemudian Tabungan dan diikuti Giro. Dari sisi pertumbuhan ke tiga instrumen DPK tersebut tampak berfluktuatif, misal pada Giro pertumbuhan signifikan terjadi pada tahun 2016 sebesar 31.9\%, sedangkan Tabungan signifikan pada tahun 2013 sebesar 26.9\% dan Deposito juga signifikan pada tahun 2013 sebesar $27,2 \%$.

\footnotetext{
${ }^{9}$ Komang WL Oka, et al., "Pengaruh Dana Pihak Ketiga, Penilaian 5C Kredit, dan Kualitas Kredit Terhadap Keputusan Pemberian Kredit di PT. Bank Pembangunan Daerah Bali Cabang Singaraja”, e-Journal S1 Ak Universitas Pendidikan Ganesha, Vol. 3 No. 1 (2015), 1 et seq.

${ }^{10}$ Departemen Perizinan dan Informasi Perbankan, "Statistik Perbankan Syariah", Otoritas Jasa Keuangan, Vol. 15 No. 01 (Desember 2016), 23.
} 
Memperhatikan fungsi pokok perbankan syariah sebagai lembaga perantara (intermediary) dan serta menyadari betapa vitalnya keberadaan Dana Pihak Ketiga bagi keberlangsungan usaha. Maka kegiatan penghimpunan DPK menjadi bagian kegiatan operasional yang selalu dapat perhatian serius dari setiap manajemen perbankan syariah.Berdasarkan pada latar belakang dan uraian yang telah dikemukakan di atas, penelitian ini bertujuan untuk mengungkap perbandingan penghimpunan dana pihak ketiga bank syariah sebelum dan sesudah kebijakan Tax Amnesty tahun 2016.

\section{Metode Penelitian}

Jenis penelitian ini adalah penelitian kuantitatif dengan pendekatan komparatif. Penelitian ini disebut penelitian kuantitatif komparatif karena membandingkan variabel yang bersifat data, yaitu Dana Pihak Ketiga bank syariah sebagai Bank Persepsi sebelum dan sesudah kebijakan Tax Amnesty tahun 2016.

Sampel penelitian ini adalah bank syariah yang ditunjuk sebagai Bank Persepsi sebagaimana dalam Keputusan Menteri Keuangan Republik Indonesia No. 600/KMK. 03/2016. Bank syariah yang dimaksud adalah Bank Muamalat Indonesia, Bank Negara Indonesia Syariah, dan Bank Syariah Mandiri. Data yang digunakan dalam penelitian ini adalah data sekunderberupa data panel publikasi laporan keuangan, yaitu gabungan data cross section dan time series 3 bank syariah kurun waktu 9 bulan sebelum dan sesudah kebijakan Tax Amnesty tahun 2016 berlangsung (Oktober 2015 - Juni 2016 dan Juli 2016 - Maret 2017). Data keuangan bank syariah tersebut yaitu meliputi Dana Pihak Ketiga yang terdiri dari Giro, Tabungan, dan Deposit.

Sumber data yang digunakan dalam penelitian ini adalah laporan keuangan yang diperoleh dari website masing-masing bank syariah penerima dana Tax Amnesty, yaitu Bank Muamalat Indonesia (www.bankmuamalat.co.id), BNI Syariah (www.bnisyariah.co.id), dan Bank Syariah Mandiri (www.syariahmandiri.co.id). Analisis data dilakukan untuk menjawab pertanyaanpertanyaan penelitian atau untuk menguji hipotesis-hipotesis penelitian yang telah dinyatakan sebelumnya. Sesudah data sekunder diperoleh, kemudian data tersebut diolah dalam bentuk tabel, menggunakan analisis data komparatif metode Paired Sample T-Tes dibantu dengan software SPSS 21 (Stastical Product and Service Solutions).

\section{Perbandingan Penghimpunan DPK Sebelum dan Sesudah Kebijakan Tax Amnesty Tahun 2016}

Dana Pihak Ketiga merupakan dana terbesar yang dimiliki oleh bank, pada tahun 2016 porsi DPK Bank Umum Syariah dan Unit Usaha Syariah di Indonesia sekitar $78.2 \%$ dibanding sumber dana lain, ${ }^{11}$ hal ini sesuai dengan fungsi bank

\footnotetext{
${ }^{11}$ Departemen Perizinan dan Informasi Perbankan,"Statistik Perbankan Syariah..., 23.
} 
sebagai penghimpun dana dari pihak-pihak yang kelebihan dana dalam masyarakat. Dana bagi bank keberadaannya sangat vital guna keberlangsungan usaha, karena tanpa dana yang cukup bank tidak akan berfungsi sebagaimana mestinya. Maka optimalisasi penghimpunan DPK menjadi sangat penting guna keberlangsungan perbankan syariah.

Penghimpunan Dana Pihak Ketiga sebelum dan sesudah kebijakan Tax Amnesty tahun 2016 pada bank syariah sebagai Bank Persepsi memiliki perbedaan yang signifikan, hal ini bisa dilihat pada hasil uji Paired Sample T-Test dalam Tabel 3.3. Rata - rata penghimpunan DPK bank syariah sebagai Bank Persepsi kurun waktu 9 bulan sebagaimana Tabel 4.1 berikut.

Tabel 3.1 Rata - Rata Penghimpunan Dana Pihak Ketiga Bank Syariah Sebagai Bank Persepsi Sebelum dan Sesudah Kebijakan Tax Amnesty Tahun 2016

\begin{tabular}{cccccc}
\hline \multicolumn{7}{c}{ Paired Samples Statistics } \\
\hline \multirow{2}{*}{ Pair 1 } & Mean & N & Std. Deviation & Std. Error Mean \\
\cline { 2 - 6 } & DPK1 & $124.129,89$ & 9 & $2.191,577$ & 730,526 \\
\hline
\end{tabular}

Sumber: Hasil Output Statistics Paired Sample T-Test SPSS 21

Berdasarkan Tabel 4.1 dapat diketahui rata-rata penghimpunan Dana Pihak Ketiga kurun waktu 9 bulan sebelum kebijakan Tax Amnesty tahun 2016 sebesar Rp 124,1 Triliun sedangkan setelah kebijakan Tax Amnesty sebesar Rp 132,9 Triliun atau naik 7,1\% dari sebelum kebijakan Tax Amnesty.Perbandingan penghimpunan DPK bank syariah sebagai Bank Persepsi sebelum dan sesudah kebijakan Tax Amnesty kurun waktu 9 bulan sebagaimana dalam grafik pada Gambar 4.2 berikut.

Gambar 3.2 Grafik Perbandingan Penghimpunan Dana Pihak Ketiga Bank Syariah Sebagai Bank Persepsi Sebelum dan Sesudah Kebijakan Tax Amnesty

Tahun 2016

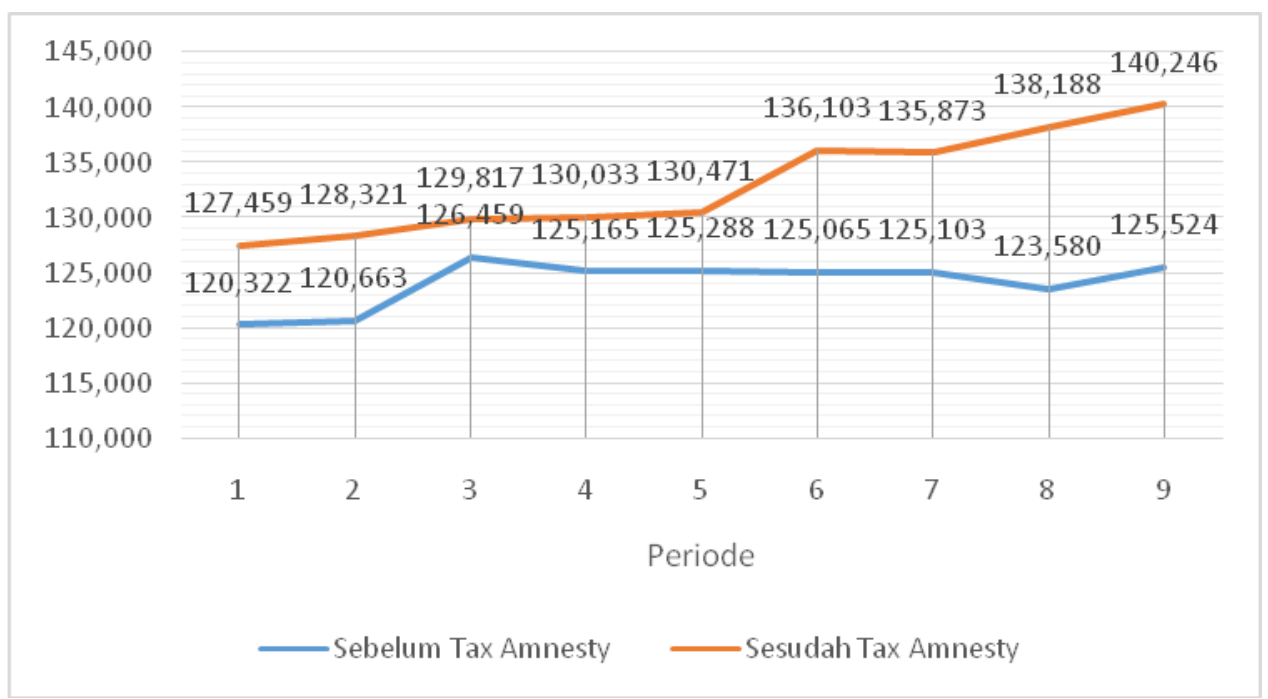

Sumber: Laporan Keuangan Bank Syariah Sebagai Bank Persepsi (diolah) 
Perbandingan penghimpunan Dana Pihak Ketiga pada Gambar 4.2 menjelaskan bahwa sesudah kebijakan Tax Amnesty tahun 2016 DPK tumbuh sebesar 11,7\% dibanding sebelum Tax Amnesty yang hanya sebesar 3,7\%. Pertumbuhan tersebut disebabkan berbagai hal, salah satunya meningkatnya jumlah nasabah bank syariah, dan menurut Ketua Dewan Komisioner Otoritas Jasa Keuangan Mualiaman D Hadad "Pertumbuhan DPK perbankan cukup tinggi merupakan pengaruh dari program pengampunan pajak atau Tax Amnesty". ${ }^{2}$ Pernyataan tersebut selaras dengan data publikasi Statistik Perbankan Syariah OJK bahwa pada tahun 2016 pertumbuhan DPK Bank Umum Syariah dan Unit Usaha Syariah sebesar 20,8\% dibanding tahun 2015 yang hanya sebesar $6 \% .^{13}$

Persentase peningkatan tersebut mengalami lonjakan signifikan dikarenakan dana repatriasi nasabah Tax Amnesty yang diterima oleh Bank Persepsi masuk sebagai Dana Pihak Ketiga. Dana repatriasi Tax Amnesty pada perbankan akan diinvestasikan dalam negeri paling singkat 3 tahun sebagaimana dalam Undang-Undang Nomor 11 Tahun 2016 Tentang Pengampunan Pajak. Maka dengan masa investasi tersebut, dana repatriasi yang masuk sebagai DPK akan membawa hal positif bagi perbankan syariah karena pertumbuhan setiap bank sangat dipengaruhi oleh perkembangan penghimpunan DPK baik berskala kecil maupun besar dengan masa investasi yang memadai. ${ }^{14}$

Dana Pihak Ketiga merupakan unsur pembentuk pendapatan bank syariah, DPK pada perbankan syariah akan disalurkan dalam bentuk pembiayaan. Kemudian pembiayaan yang disalurkan tersebut akan diperoleh tingkat pengembalian berupa margin, besar kecilnya margin akan menentukan tingkat profitabilitas. ${ }^{15}$ Dana Pihak Ketiga juga merupakan bagian terpenting dalam basis keputusan atau kebijakan dalam bank, karena semakin besar DPK maka keputusan pemberian pembiayaan akan semakin tinggi. DPK berpengaruh positif terhadap penyaluran pembiayaan. ${ }^{16}$

Pembiayaan yang disalurkan perbankan syariah merambah ke berbagai sektor, salah satunya sektor Usaha Mikro Kecil dan Menengah (UMKM). Porsi pembiayaan perbankan syariah terhadap sektor UMKM per Juli 2017 sebesar Rp 55,4 Triliun atau 20,9\%. ${ }^{17}$ Jika produktivitas UMKM dapat ditingkatkan salah satunya dengan kucuran dana perbankan, maka dari sektor UMKM akan mampu mendongkrak Pendapatan Domestik Bruto dan menyerap pengangguran. Sehingga kekuatan ekonomi suatu negara memiliki korelasi yang positif dengan

\footnotetext{
${ }^{12}$ Sakina Rakhma D. Setiawan, Tax Amnesty Dorong Pertumbuhan Dana Pihak Ketiga Perbankan Tahun 2016, diakses pada tanggal 27 dari http://ekonomi.kompas.com/read/2016/12/30/

123000026/.tax.amnesty.dorong.pertumbuhan.dpk.perbankan.tahun.2016.

${ }^{13}$ Departemen Perizinan dan Informasi Perbankan,"'Statistik Perbankan Syariah..., 23.

14 Teti Rahmawati, “Analisis Perbandingan Penghimpunan..., 76.

${ }^{15}$ Maltuf Fitri, "Peran Dana Pihak Ketiga..., 74.

${ }^{16}$ Komang WL Oka, et al., "Pengaruh Dana Pihak Ketiga..., 1 et seq.

${ }^{17}$ Departemen Perizinan dan Informasi Perbankan, "Statistik Perbankan Syariah", Otoritas Jasa Keuangan, Juli 2017, 33.
} 
kontribusi UMKM terhadap perekonomian suatu negara. Semakin besar kontribusi UMKM terhadap perekonomian maka semakin kuat ekonomi negara tersebut. $^{18}$

Dalam pandangan syariah, uang (dana) bukanlah merupakan suatu komoditi melainkan hanya merupakan alat untuk mencapai pertambahan nilai ekonomis (ecconomic added value). Untuk menghasilkan keuntungan dana harus dikaitkan dengan kegiatan ekonomi dasar (primary ecconomic activities) seperti perdagangan, industri, sewa menyewa dan lain sebagainya. ${ }^{19}$ Berikut ini adalah firman Allah yang berhubungan dengan pemanfaatan dana:

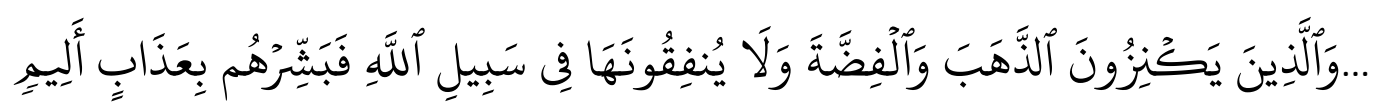

Artinya: “...Dan orang-orang yang menyimpan emas dan perak dan tidak menafkahkannya pada jalan Allah, maka beritahukanlah kepada mereka, (bahwa mereka akan mendapat) siksa yang pedih", (QS. At-Taubah [34]: 9). ${ }^{20}$

Ayat tersebut berupa ancaman bagi pihak yang suka menyimpan harta dari emas dan perak di dunia, yaitu berupa siksaan di akhirat. Artinya ada larangan tegas dan keras bagi pemilik dana yang tidak mau mengedarkannya atau menyalurkannya pada orang lain. Fakta dari beberapa penelitian tersebut dapat disimpulkan bahwa kebijakan Tax Amnesty tahun 2016 memberikan efek positif pada kinerja keuangan perbankan syariah melalui optimalisasi Dana Pihak Ketiga. Implikasinya, DPK akan berkontribusi terhadap kinerja keuangan perbankan salah satunya profitabilitas bank, dan pembiayaan yang disalurkan akan menguatkan perekonomian suatu negara.

\section{Analisis Statistik}

Statistik deskriptif digunakan untuk melihat gambaran data Dana Pihak Ketiga yang akan digunakan. Output statistik deskriptif akan menampilkan nilai mean, median, maximum, dan nilai minimum. Statistik deskriptif data DPK sebelum dan sesudah kebijakan Tax Amnesty tahun 2016adalah sebagaimana dalam Tabel 3.1 berikut.

\footnotetext{
${ }^{18}$ Nasaruddin Malik dan MSW Suliswanto, ed.,Membangun Ekonomi Nasional Yang Kokoh: Kajian dan Pengalaman Empiris (Malang: UMM Press, 2015), 261.

${ }^{19}$ Zainul Arifin, Dasar-Dasar Manajemen Bank Syariah (Jakarta: Azkia Publisher, 2009), 57.

${ }^{20}$ Departemen Agama RI, al-Qur'an dan Terjemahannya..., 192.
} 
Tabel 4.1 Statistik Deskriptif Data Dana Pihak Ketiga Sebelum dan Sesudah Kebijakan Tax Amnesty Tahun 2016

\begin{tabular}{llrrr}
\hline \multicolumn{5}{c}{ Descriptive Statistics } \\
\hline $\mathrm{N}$ & DPK-1 & DPK-2 & Valid N (listwise) \\
\hline Minimum & Statistic & 9 & 9 & 9 \\
Maximum & Statistic & 120.322 & 127.459 & \\
Median & Statistic & 126.459 & 140.246 & \\
Mean & Statistic & 125.103 & 130.471 & \\
\hline Sumber: Output & Statistic & $124.129,89$ & $132.945,67$ &
\end{tabular}

Sumber: Output Descriptive Statistics SPSS 21

Berdasarkan output descriptive statistics SPSS pada Tabel 3.1 dapat diketahui bahwa jumlah sampel (N) data Dana Pihak Ketiga yang dipakai baik sebelum Tax Amnesty (DPK-1) maupun sesudah Tax Amnesty (DPK-2) adalah 9, hal ini sesuai dengan kurun waktu pelaksanaannya kebijakan Tax Amnesty tahun 2016 selam 9 bulan. Nilai minimum atau nilai penghimpunan terendah DPK-1 sebesar Rp 120,3 Triliun sedangkan penghimpunan DPK-2 sebesar Rp 127,4 Triliun. Nilai maximum atau nilai penghimpunan tertinggi DPK-1 sebesar Rp 126,4 Triliun sedangkan DPK-2 sebesar Rp 140,2 Triliun. Nilai median atau nilai tengah penghimpunan DPK-1 sebesar Rp 125,1 Triliun sedangkan DPK-2 sebesar Rp 130,4 Triliun. Adapun nilai penghimpunan rata-rata atau mean DPK-1 sebesar Rp 124,1 sedangkan DPK-2 sebesar Rp 132,9 Triliun.

\subsection{Uji Normalitas}

Uji normalitas bertujuan untuk menguji apakah dalam model uji Paired Sample T-Test memiliki data terdistribusi normal. Syarat uji beda dua rata-rata dengan metode Paired Sample T-Test mengasumsikan bahwa data mengikuti distribusi normal. Kalau asumsi ini dilarang maka uji statistik menjadi tidak valid. ${ }^{21}$ Uji normalitas data pada penelitian ini menggunakan uji skewness dan kurtosis. Hasil uji skewness dan kurtosis Dana Pihak Ketiga sebelum dan sesudah kebijakan Tax Amnesty tahun 2016 sebagaimana Tabel 3.2 berikut.

Tabel 4.2 Hasil Uji Normalitas Data Dana Pihak Ketiga Sebelum dan Sesudah Kebijakan Tax Amnesty Tahun 2016

\begin{tabular}{llrrr}
\hline & & DPK-1 & DPK-2 & Valid N (listwise) \\
\hline $\mathrm{N}$ & Statistic & 9 & 9 & 9 \\
\multirow{2}{*}{ Skewness } & Statistic & $-1,180$ &, 400 &, 717 \\
& Std. Error &, 717 & $-1,591$ & \\
\multirow{3}{*}{ Kurtosis } & Statistic &,- 013 & 1,400 & \\
& Std. Error & 1,400 & & \\
\hline
\end{tabular}

Sumber: Output Skewness dan Kurtosis SPSS 21

\footnotetext{
${ }^{21}$ Imam Ghozali, Aplikasi Analisis Multivariate dengan Program IBM SPSS 21 Update PLS Regresi (Semarang: Badan Penerbit Universitas Diponegoro, 2013), 160.
} 
Hasil uji normalitas pada Tabel 3.2 diketahui nilai statistik skewness dan kurtosis Dana pihak Ketiga sebelum Tax Amnesty (DPK-1) sebesar -1,180 dan 0,400 dan sesudah Tax Amnesty (DPK-2) sebesar -0,013 dan -1,591. Berdasarkan hipotesis uji skewness dan kurtosis dengan melihat range nilai jika terletak antara -2 hingga 2, variabel data tersebut akan mengikuti distribusi normal. ${ }^{22}$ Maka Dana Pihak Ketiga sebelum dan sesudah kebijakan Tax Amnesty tahun 2016 telah mengikuti distribusi normal.

\subsection{Uji Paired Sample T-Test}

Pengujian hipotesis Paired Sample T-Tes dilakukan terhadap dua sampel yang berpasangan (paired). Sampel yang berpasangan diartikan sebagai sebuah sampel dengan subjek yang sama namun mengalami dua perlakuan atau pengukuran yang berbeda. ${ }^{23}$ Uji inidilakukan dengan bantuan software SPSS, dasar pengambilan keputusan jika $\alpha P$-value $\mathrm{t}=>0,05$, maka Ho diterima, dan jika $\alpha$ nilai $P$ value $=<0,05$, maka Ho ditolak. ${ }^{24}$ Hasil uji Paired Sample T-Tes Dana Pihak Ketiga sebelum dan sesudah kebijakan Tax Amnesty tahun 2016 sebagaimana dalam Tabel 3.3 berikut.

Tabel 4.3 Hasil Uji Paired Sample T-TestDana Pihak Ketiga Bank Syariah Sebagai Bank Persepsi Sebelum dan Sesudah Kebijakan Tax Amnesty Tahun 2016

\begin{tabular}{|c|c|c|c|}
\hline \multicolumn{4}{|c|}{ Paired Samples Test } \\
\hline & & & Pair 1 \\
\hline & & & DPK-1 - DPK-2 \\
\hline \multirow{5}{*}{$\begin{array}{l}\text { Paired } \\
\text { Differences }\end{array}$} & Mean & & $-8.815,778$ \\
\hline & Std. Deviation & & $4.182,085$ \\
\hline & Std. Error Mean & & $1.394,028$ \\
\hline & 95\% Confidence Interyal of the Difference & Lower & $-12.030,413$ \\
\hline & 95\% conmence interval on the Dimerence & Upper & $-5.601,143$ \\
\hline $\mathrm{T}$ & & & $-6,324$ \\
\hline Df & & & 8 \\
\hline Sig. (2-tailed) & & &, 000 \\
\hline
\end{tabular}

Berdasarkan hasil output Paired Sample T-Test dalam Tabel 3.3 tersebut dapat diketahui $\alpha P$-value t pada kolom Sig. (2-tailed) adalah sebesar 0,000 $(<0,05)$, maka kesimpulannya adalah $\mathrm{H}_{0}$ ditolak dan $\mathrm{H}_{1}$ diterima. Artinya terdapat perbedaan signifikan rata-rata penghimpunan Dana Pihak Ketiga bank syariah sebelum dan sesudah kebijakan Tax Amnesty tahun 2016.

\footnotetext{
${ }^{22}$ Sofyan Yamin dan Heri Kurniawan, SPSS Complete: Teknik Analisis Statistik Terlengkap dengan Software SPSS (Jakarta: Salemba Infotek, 2014), 16.

${ }^{23}$ Ibid, 56.

${ }^{24}$ Ibid, 57.
} 


\section{Penutup}

Berdasarkan data dan hasil analisis yang telah dilakukan, peneliti menemukan sejumlah temuan yang dapat dijadikan sebagai kesimpulan penelitian. Fakta-fakta temuan tersebut menjadi jawaban dan bagian akhir atas pertanyaan awal pada rumusan masalah di saat penyusunan penelitian. Maka untuk memperoleh gambaran hasil penelitian yang lebih komprehensif, berikut adalah kesimpulan dari penelitian ini. Penghimpunan Dana Pihak Ketiga bank syariah sebagai Bank Persepsi sebelum dan sesudah kebijakan Tax Amnesty tahun 2016 terdapat perbedaan yang signifikan. Peningkatan penghimpunan DPK mengalami lonjakan signifikan dikarenakan dana repatriasi nasabah Tax Amnesty yang diterima oleh Bank Persepsi masuk sebagai DPK.

Setelah melakukan penelitian dan menarik kesimpulan dari penelitian ini, maka peneliti memberikan saran sebagai berikut: pertama, bagi Perbankan Syariah, sebagai bahan evaluasi untuk meningkatkan kinerjanya agar kebijakan-kebijakan pemerintah berikutnya bank syariah yang selain Bank Muamalat Indonesia, BNI Syariah, dan Bank Syariah Mandiri bisa diikut sertakan. kedua, bagi pembuat kebijakan, sebagai bahan pertimbangan agar dalam kebijakan berikutnya jika melibatkan bank, proporsi jumlah bank syariah dalam kebijakan bisa dipertimbangkan lagi. Karena bank syariah yang masih baru atau dalam tahap perkembangan masih membutuhkan stimulus percepatan pertumbuhan melalui kebijakan - kebijakan yang strategis. ketiga, keterbatasan dalam penelitian ini adalah peneliti hanya menguji perbandingan Dana Pihak Ketiga sebelum dan sesudah kebijakan Tax Amnesty. Bagi peneliti selanjutnya bisa menambahkan variabel lain yang mungkin akan berhubungan dengan kinerja DPK, Biaya Operasional terhadap Pendapatan Operasional (BOPO), Return Of Aset (ROA), dan Loan to Deposit Rasio (LDR) atau variabel lain yang mencerminkan kinerja keuangan perbankan syariah.

\section{Daftar Pustaka}

Departemen Agama RI. (2011). Al-qur'an dan Terjemahannya. Jakarta: Lentera Abadi.

Departemen Perizinan dan Informasi Perbankan. (2017, Juli). Statistik Perbankan Syariah. Otoritas Jasa Keuangan. 5, 33. . (2017, Juni). Statistik Perbankan Indonesia. Otoritas Jasa Keuangan. Vol. 15 No. 1. 23.

Fitri, Maltuf. (2016, Mei). Peran Dana Pihak Ketiga dalam Kinerja Lembaga Pembiayaan Syariah dan Faktor-faktor yang Mempengaruhinya. Economica. Vol. VII Ed. 1. 74.

Ghozali, Imam. (2013). Aplikasi Analisis Multivariate dengan Program IBM SPSS 21 Update PLS Regresi. Semarang: Badan Penerbit Universitas Diponegoro. 
Malik, Nasaruddin dan MSW Suliswanto. (Ed.). (2015). Membangun Ekonomi Nasional Yang Kokoh: Kajian dan Pengalaman Empiris. Malang: UMM Press.

Mudawamah. (2015). Penyanderaan (Gijzeling) Terhadap Wajib Pajak Pribadi yang Tidak Kooperatif. Skripsi Sarjana Hukum Bisnis Syariah Fakultas Syariah yang tidak diterbitkan, UIN Malik Ibrahim, Malang.

Oka, Komang Wulan Lestari, et al. (2015). Pengaruh Dana Pihak Ketiga, Penilaian 5C Kredit, dan Kualitas Kredit Terhadap Keputusan Pemberian Kredit di PT. Bank Pembangunan Daerah Bali Cabang Singaraja. e-Journal S1 Ak Universitas Pendidikan Ganesha. Vol. 3 No. 1. 1. Et seq.

Rahmawati, Teti. (2015). Analisis Perbandingan Penghimpunan Dana Pihak Ketiga Pada Perbankan Syariah Sebelum dan Sesudah Penerapan Kebijakan Office Chanelling. Jurnal Riset Keuangan dan Akuntansi. Vol. 1 No. 2. 76.

Rivai, Veithzal, et al. (2007). Bank and Financial Institution Management: Conventional \& Sharia System. Jakarta: Rajawali Pers.

Yamin, Sofyan dan Heri Kurniawan. (2014). SPSS Complete: Teknik Analisis Statistik Terlengkap dengan Software SPSS. Jakarta: Salemba Infotek.

Setiawan, Sakina Rakhma D (2016). Tax Amnesty Dorong Pertumbuhan Dana Pihak Ketiga Perbankan Tahun 2016. Diakses pada tanggal 27 dari http://ekonomi.kompas.com/read/2016/12/30/123000026/.tax.amnesty.doro ng.pertumbuhan.dpk.perbankan.tahun.2016.

Yang Perlu Anda Tahu Tentang Amnesti Pajak. Diakses pada tanggal 28 Juli 2017 dari http://pajakku.com/page/detail/999/yang-perlu-anda-tahu-tentangamnesti-pajak. 